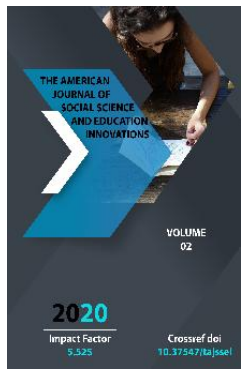

\title{
Linguo-Cultural Aspects Of Anthroponyms Used In Samples Of Uzbek Folklore
}

\author{
Zaripov Botir Pulatovich \\ (Phd) Associate Professor Of Navoi State Pedagogical Institute, Uzbekistan
}

Journal Website:

http://usajournalshub.c

om/index,php/tajssei

Copyright: Original

content from this work

may be used under the

terms of the creative

commons attributes

4.0 licence.

\section{ABSTRACT}

The article describes some of the names used in folk tales and fairy tales and their meanings, the connection between the fate of the hero and his name, the events described in the play and the linguocultural aspects of the names of the heroes.

\section{KEYWORDS}

Epics and fairy tales, names of heroes, meaning, function of the name, linguocultural symbols

\section{INTRODUCTION}

Linguoculturology studies language as a cultural phenomenon, a carrier of culture. Culture is created by a person who uses language. [1. p.26] The subject of linguoculturology is the units of language that have a symbolic, figurative, metaphorical meaning in culture and whose results are generalized in the human mind and reflected in myths, legends, folklore, poetic and prose texts, phraseology, metaphors and symbols. It should be noted that anthroponyms are also one of the main units that reflect the national and cultural characteristics of the people as a linguocultural unit.

It is known that the language of each nation is reflected in its literature. The history, mentality and culture of the people are reflected in the works of art created in this language. These features, in turn, require linguocultural analysis.

The Uzbek people are one of the ancient Turkic peoples with a long history and rich cultural heritage. The language of any nation 
is also the wealth of that nation. As language is a social phenomenon, it develops, enriches, and refines itself in connection with the life of the people to whom it belongs. The works created in any period contain information about the thinking, worldview, lifestyle, morals, work, and living conditions of the people of that period, as well as information about their ancestors, all of them were reflected in the literature.

Regardless, when a work of art is created, there are characters in the work, and their names represent a specific purpose or idea in the work. Even in folklore, choosing a name for a hero requires some thought. In some works, the name of the protagonist is an important tool in revealing the idea expressed in the play.

\section{MATERIALS AND METHODS}

Naming is always done through a specific purpose, a certain concept and imagination, a belief, a belief, and a ritual. This is especially true when naming a child or naming certain places and places. [2] The beliefs and rituals associated with naming have been around since ancient times and have become a definite ethnographic tradition. We see that the following principles have been followed in such ethnographic traditions:

1. Choose a suitable name;

2. Attitude to the given name;

3. Protection of the name;

4. National-spiritual and aesthetic assessment of the name;

5. Update the name fund according to the requirements of the period and conditions.

This feature is encountered in the process of collecting and studying famous names in the language, and it is necessary to name in one way or another the concepts, ideas, beliefs and convictions, ethnographic customs, traditions, images and customs. This creates terms related to the ethnographic basis of names. These are:

1. Terms that refer to the process of naming a baby or a geographical object: naming, naming, naming, naming rituals, naming, naming, naming custom, naming a child, choose a name for the baby, give a suitable name, etc. $b$.

2. Naming rituals, terms denoting beliefs: anonymity (names), custodial names (names), dedication (memorial) names, name-wishes (descriptive), name by itself, name change, child renaming, nameless walking, awkward naming, negative names, descriptive names, euphemistic names, proper names, hard-featured name, boy name, girl name, ethnography of names and etc.

Some of the terms in this group include terms related to taboos and euphemisms. These terms refer to the concepts and notions associated with the habit of keeping a baby's name secret, naming a child with a double name, or not naming it for a certain period of time: keeping a name secret (taboo), taboo name, totemic name, totem based names, such as totem-ethnonyms, real name concealers, double names, double names, neighborhood, child's pseudonym.

3. Terms related to the cultural, spiritual and aesthetic evaluation of the name (attitude to the name):

- Positive evaluation terms: beautiful name, beautiful name (name), beautiful names, 
worthy name (name), beautiful name in content, good name (name);

- Negative evaluation terms: nonsense, unbeautiful names, pompous names, discriminatory names, non-cultural names, unbeautiful names in content, inappropriate names, inappropriate names, names with awkward meanings, unbeautiful names, unbeautiful meaningful names, old names, and so on.

Terms that refer to certain ethnographic and scientific concepts related to the process of naming a person or an object can also be included in this group: child naming habits, child naming habits, naming given at a young age, naming habits, basics of naming, series of names, recommendation of names, culture of the name, quantitative reduction of the fund of names, ethnographic meaning of the name, appreciation of the name, respect for the name, methods of naming, basics of naming, naming culture, naming art as. [3] All of these are linocultural factors.

Nicknames can be used in works as well as names. Names, nicknames, and nicknames are created because of the need to distinguish one distinct person from another. A nickname is an additional name given to a person by a joke or ridicule. A nickname is also a name that has been changed for a specific purpose. Works of art can also be used in conjunction with a person's name for various purposes, or the nickname itself. Of course, nicknames can also have aspects related to the idea of the work as a means of revealing the heroic character. [4] The above-mentioned names and their features are also observed in the samples of folklore, which is the golden fund of our people.

\section{RESULTS AND DISCUSSIONS}

In folk tales and epics, the names of heroes who defend the interests of the people always have a positive meaning. For example: Muqbil, Qilich botir, Odilxon, Bahodir, Dono, Sahibjamol. On the contrary, people blame names for expressing anger and hatred towards negative heroes (such as Maqotil, Mudbir, Egri).

When you hear and read the names of the positive characters in fairy tales and epics, you have a positive impression. It has to do with that name.

In ancient times, when a baby was born, the time, place, state of health, individual characteristics, and other factors of the child's birth were determined by his or her lineage. The same is true of folklore.

Also, on the basis of the naming of any child, the beliefs of our ancestors in the past about the cultural, social, socio-economic life of the tribal and tribal period, as well as the historical stages of the formation of the people and the nation. This phenomenon can be seen in the epic "Alpomish", which is considered a rare masterpiece of folklore. For example: Dobonbi passed in Kungrad. Dobonbi had a son named Alpinbi. Alpinbi had two sons: Boybori and Boysari. The "biy" component in the names of Dobonbiy and Alpinbiy represents the class of the owners of this name: biy, i.e. rich. The "rich" part of the names Boybori and Boysari also has the same meaning, meaning that they belong to the upper class. Kultoy is a servant. You can tell by his name.

Alpomish's real name is Hakimbek. Hakimbek takes the name of Alpomish after capturing Boychibor and raising fourteen batman bows. 
Alp means wrestler, brave. It should be noted that the epic is also called by this name.

Alpomish's son's name is Yodgor. A child whose father did not return from the war or whose father died before the child was born was named Yodgor. Alpomish was in prison when his son was born. (He was imprisoned for seven years. He was thought to be dead.) That is why his son is named Yodgor.

In the epic "Kuntugmish" you can see that the names are connected with the fate of the heroes: Kuntugmish and Holbeka have twins. The merchant Azbarkhoja betrays Kuntugmish to take Kholbek to the king. He gets drunk, wraps her in felt, and puts a stone on her. Kuntugmish comes to his senses and finds his children. She is trying to swim across the river with her two children. One of them was bitten by a wolf and swam across the river. The boy is afraid and says, "Father." The father saw that the child was being taken away by a wolf. When he says, "Wow," that son falls into the water. The fish swallows what falls into the water.

The fish that swallows the baby of the night falls into the net. When the fishermen look through his belly, a child emerges. This baby is called Mohiboy .Mohi means fish. The shepherds let go of their dogs when they saw a wolf biting the boy. The wolf abandons the child and runs away. The shepherds called the wolf a wolf. That's why the boy's name is Gurkiboy. Kuntugumish's children are called by these names in the epic. One of the most interesting and touching events in the story is the adventures of Mohiboy and Gurkiboy.

Kuntugmish has the word "kun" (day) in its name. The word "kun" evolved from the word "kun", which meant "sun" in ancient Turkic.
[5] The sun is the basis for life, for humanity and the most essential source of life. Many honorable things are attributed to the sun. This indicates that the semantic "positivity" is strong in the semantic structure of the solar lexeme. Used as part of the hero's name which is interpreted as a positive image. Therefore, the name Kuntugmish means "wealth, a symbol of the state." Although the protagonists of the saga go through many events, at the end of the saga they all achieve their goals.

In the epic Ravshan, Ravshanbek names Goroglybek Hasankhan's son "Let my father's name not be lost". Gorogly's father's name was Ravshan. Even today, it is customary to pass on the names of grandparents to future generations. The name Ravshan means "bright, shining, or a bright future."

In fairy tales, the names of the heroes who defend the interests of the people always have a positive meaning. For example: In the fairy tale "Muqbil toshotar" the name of the main character is Muqbil. Muqbil in Arabic means "lucky, happy", the name of the negative hero - Mudbir in Arabic means "backward, unhappy". The story ends like this: Mudbir dies because of his rebellion and lies. Muqbil, for the sake of honesty and purity of heart, will survive the hardships that come his way. They achieve their goals for the sake of honesty and nobility. The content, the idea and the conclusion at the end of the story are directly related to the semantic nature of the names of the protagonists.

The fairy tale "Odilkhan" is also named after a man. Odil means "just"; As a historian, the khan "represents the title by joining the name of the person who ruled, the khan" [6]), Bahodir (meaning: "brave, fearless"), the 
name of the girls - Dono (meaning: "knowledgeable, intelligent" "intelligent"), Sahibjamol (meaning "beautiful beauty") are interpreted as positive heroes.

Names are also used to express anger and hatred towards negative heroes: Maqotil (meaning "murderer"), Mudbir, Egri.

\section{CONCLUSION}

In ancient times, our ancestors practiced naming, among other things. The name of the child depends on the tribe, the time of birth, the state of health, the characteristics of the child's body and other factors. The same is true of folklore. If we pay attention to folk epics and fairy tales, the name of the protagonist is taken as the title or title of the work. The three epics mentioned above are named after the protagonists. These titles are the first signs that embody the general idea of the work and reflect the specific nationalcultural features and mentality of the Turkic peoples. The semantics of the anthroponyms analyzed above also reflect aspects related to the national-spiritual characteristics, social lifestyle and worldview, beliefs, traditions and customs of the people.

\section{REFERENCES}

1. Usmanova Sh. Lingvokulturologiya.T .: 2019. 26-p.

2. Begmatov E. Names and people. - $\mathrm{T}$.: Science, 1966;

3. Nuritdinova R.S. Linguistic analysis of the terms of Uzbek onomastics. Candidate's dissertation. T.2005. p.48-49.

4. Surayyo Muqimova. Linguopoetic features of nicknames used in works of art. Khorezm. Sources of knowledge. 2019. Issue 8.p.123
5. Sevortyan E. V. Etimologicheskiy slovar tyurskiy yazykov. I-IV tomov. M.1945. p101.

6. Annotated dictionary of the Uzbek language. Volume 4 T.2008.p.410

7. Jumayevna Y. N. Linguo culture logical features of metaphors in children's literature (On the example of Khudayberdi Tokhtabayev's creative work) //ACADEMICIA: An International Multidisciplinary Research Journal. 2019. - T. 9. - №. 4. - p. 139-145.

8. Nigora M. The historical development of the language-the basis of human history //International Journal on Integrated Education. - 2019. - T. 2. - №. 4. P.119-121. 